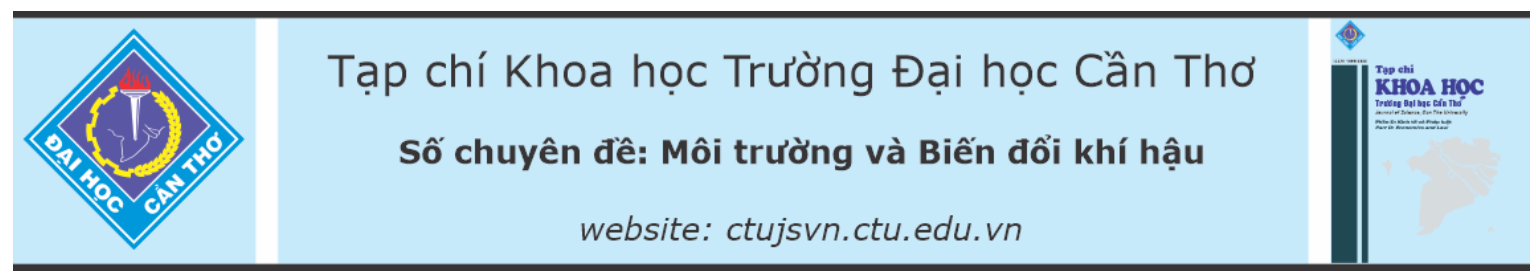

DOI:10.22144/ctu.jsi.2021.028

\title{
ĐÁNH GIÁ HIỆU QUẢ XỬ LÝ RÁC THẢI HŨ̉U CƠ CỦA VI KHUẨN TỒN TRŨ TRONG CÁC ĊHÂT MANG
}

\author{
Đỗ Thị Xuân ${ }^{1 *}$, Nguyễn Thiện Mỹ², Cao Thị Mỹ Tiên ${ }^{1}$, Nguyễn Thị Cẩm Hơn ${ }^{2}$, \\ Nguyễn Hoàng Hậu ${ }^{2}$, Nguyễn Phạm Anh Thi ${ }^{1}$, Bùi Thị Minh Diệu ${ }^{1}$ và Võ Dương Lan Anh ${ }^{2}$ \\ ${ }^{1}$ Viện Nghiên cứu và Phát triển Công nghệ Sinh học, Truờng Đại học Cần Tho \\ ${ }^{2}$ Sinh viên ở Viện Nghiên cúu và Phát triển Công nghệ Sinh học, Truờng Đại học Cần Tho \\ *Nguời chịu trách nhiệm về bài viết: Đố Thị Xuân (email: dtxuan@ctu.edu.vn)
}

\section{Thông tin chung:}

Ngày nhận bài: 12/04/2021

Ngày nhận bài sủa: 18/10/2021

Ngày duyệt đăng: 15/11/2021

\section{Title:}

Evaluation of organic household wastes degrading bacteria isolated and preserved in organic carriers

\section{Tù khóa:}

Chất mang, hoạt tính enzyme, rác thải sinh hoạt hũu co, vi khuẩn phân hủy rác thải

\section{Keywords:}

Bacterial strains degrading domestical organic waste, carrier, domestical organic waste, enzymatic activity

\begin{abstract}
The study aims at identifying carriers to evaluate density and activities of three functional bacterial isolates preserved in four different organic residues carriers and their efficacy after storage on degrading organic household wastes. The density and activities of bacterial strains were investigated during the incubation period. Bacterial inoculants from the efficient storage carriers were mixed each other $(w / w)$ and used to evaluate its efficiency on treating household waste under laboratory conditions. After 6 months of storage, the density of three bacterial strains maintained over $8 \log C F U / g$ in the carriers. In particular, ground coir showed the best carrier for maintaining the density of pTVC3 and cATI and rice bran carrier was the best for aCRI, giving density above $7 \log C F U / g$ carriers, respectively. The enzymatic activities of these three strains were also maintained for up to 6-month storage. The organic household waste treated by the mixture of the inoculant treatments decomposed significantly and reached $80 \%$ at 3 days after inoculation. The product from the organic household waste had no odor, low density of E. coli, soft and met the regulations on the safety and quality of organic fertilizer.
\end{abstract}

\section{TÓM TĂT}

Nghiên cứu được thực hiện nhằm đánh giá khả năng duy trì mật số và hoạt tính của ba dòng vi khuẩn (VK) chức năng được tồn trũ trong bốn loại chất mang và hiệu quả xử lý rác thải sinh hoạt hữu co sau thời gian tồn trũ. Mật số và hoạt tính của các dòng VK được khảo sát thời gian tồn trũ. Chế phẩm thử nghiệm gồm các VK tồn trũ hiệu quả trong các chất mang được sủ dụng để đánh giá hiệu quả phân hủy rác thải hũu co. Sau 6 tháng tồn trũ, chẩt mang xơ dì̀ giúp duy trì mật số tốt nhất cho dòng $p T V C 3$, cATl và chất mang cám gạo thích hợp với dòng aCR1 với mật số VK trên $7 \log C F U / g$ chất mang. Hoat tính enzyme của ba dòng VK vẫn được duy trì sau 6 tháng. Nghiệm thức chế phẩm thử nghiệm cho hiệu quả phân hủy rác thải sinh hoạt hũu co đạt $80 \%$ ở 3 ngày sau ủ. Sản phẩm tì̀ rác thải sau khi phân hủy đạt tiêu chuẩn Việt Nam về mùi, độ an toàn và chát luợng của phân hũu co:

\section{1. ĐẶT VẤN ĐỀ}

Hiện nay, một trong những đặc điểm rõ nhất ở chất thải đô thị Việt Nam là thành phần các chất hữu cơ chiếm tỷ lệ khá cao (55 - 65\%) (Nguyễn Xuân Thành, 2003). Tại thành phố Cần Thơ, theo kết quả điều tra tỉ lệ rác thải hữu cơ được thải bỏ chiếm khoảng $91,54 \%$ trong tổng lượng rác thải được thu 
gom mỗi ngày, trong đó rác thải từ thực vật chiếm khoảng $61,87 \%$ và từ động vật chiếm khoảng 29,67\% (Nguyễn Hoàng Hậu, 2020). Với nguồn rác thải hữu cơ dồi dào và ổn định, việc xử lý rác thải sinh hoạt hữu cơ bằng công nghệ vi sinh vật có sự tham gia của các nhóm vi sinh vật chức năng như nhóm vi sinh vật phân hủy cellulose, phân hủy tinh bột và phân hủy protein để sản xuất phân hữu cơ là rất thuận lợi và hiệu quả (Hà Thanh Toàn và ctv., 2008).

Đồng bằng sông Cửu Long có lợi thế là vùng sản xuất nông nghiệp chính nên các phụ phế phẩm nông nghiệp như bã mía, mụn dừa, cám gạo, trấu rất dồi dào. Các phụ phế phẩm này có thể được tận dụng để làm nguồn chất mang cho các dòng vi khuẩn $(\mathrm{VK})$ có lợi giúp phân hủy rác thải hữu cơ vừa rẻ tiền vừa góp phần giảm ô nhiễm môi trường, nâng cao giá trị của các phụ phế phẩm nông nghiệp. Do đó, nghiên cứu được thực hiện với mục tiêu đánh giá khả năng duy trì mật số và hoạt tính của ba dòng VK chức năng được tồn trữ trong các chất mang khác nhau và hiệu quả xử lý rác thải sinh hoạt hữu cơ sau thời gian tồn trữ.

\section{VÂT LIỆU VÀ PHƯƠNG PHÁP NGHIẾN CÚU}

\subsection{Vật liệu thí nghiệm}

VK: Ba dòng VK bao gồm 1 dòng phân giải protein $p . T V C 3,1$ dòng phân giải cellulose cAT1 và 1 dòng phân giải tinh bột aCR1 đã được phân lập, tuyển chọn từ các nguồn rác thải sinh hoạt hữu cơ tại thành phố Cần Thơ với hiệu suất phân hủy thịt vụn, cá vụn, rau cải thừa và tinh bột gạo của từng dòng VK đạt trên $75 \%$ sau 15 ngày xử lý (Nguyễn Hoàng Hậu, 2020). Các dòng VK được lưu trữ tại Phòng thí nghiệm Vi sinh vật, Viện Nghiên cứu và Phát triển Công nghệ Sinh học, Trường Đại học Cần Tho.

Chất mang: Bã mía được thu gom tại các xe bán nước mía tại thành phố Cần Thơ, xơ dừa được thu mua tại cửa hàng vật tư nông nghiệp tại thành phố Cần Thơ, trấu xay được thu mua tại nhà máy Duy Phát tại Đồng Tháp, cám gạo được thu mua tại cửa hàng gạo ở thành phố Cần Thơ.

Mẫu rác thải hữu cơ: Là các thành phần hữu cơ như phế phụ phẩm nhà bếp (rau cải, trái cây, cơm thừa, thịt, cá...) các loại lá cây, cỏ được giữ lại từ các mẫu rác sinh hoạt của người dân trên địa bàn thành phố Cần Thơ sau khi được thu gom và loại bỏ các thành phần vô cơ (nhựa, nylon, vỏ lon, kính...), những vật cứng (xương, cây gỗ...).
Môi trường nuôi cấy $\mathrm{VK}$ : Môi trường phân giải protein (proteolytic bacteria, PB) (Hà Thanh Toàn, 2008) có hiệu chỉnh với các thành phần như sau $(\mathrm{g} / \mathrm{L})$ : 5 peptone, 3 meat extract, 1 yeast extract, 20 sữa bột skim milk $\mathrm{A} 2,20$ agar và bổ sung nước cất để đạt thể tích $1000 \mathrm{~mL}$. Môi trường nuôi cấy VK phân giải cellulose bao gồm $(\mathrm{g} / \mathrm{L}): 1\left(\mathrm{NH}_{4}\right)_{2} \mathrm{SO}_{4}$, $1 \mathrm{~K}_{2} \mathrm{HPO}_{4}, 0,5 \mathrm{MgSO}_{4}, 0,009 \mathrm{NaCl}, 10 \mathrm{CMC}, 0,2$ Cycloheximide, 20 agar (cellulolytic bacteria, CB) (Ryckeboer et al., 2003). Môi trường nuôi cấy VK phân giải tinh bột bao gồm $(\mathrm{g} / \mathrm{L})$ : $9 \mathrm{NH}_{4} \mathrm{Cl}, 0,5$ $\mathrm{K}_{2} \mathrm{HPO}_{4}, 0,5 \mathrm{MgSO}_{4} .7 \mathrm{H}_{2} \mathrm{O}, 3 \mathrm{CaCO}_{3}, 20$ Glucose, 10 tinh bột tan, 20 agar (amylolytic bacteria, AB) (Arbaciauskiene, 2003).

\subsection{Phương pháp}

\subsubsection{Khảo sát khả năng sống sót và duy trì hoạt tính của các dòng VK trên các công thức chất mang}

Xử lý chất mang: Bã mía được rửa lại với nước đến khi độ Brix dưới $1^{0}$ sau đó phơi khô và xay nhuyễn. Xơ dừa được ngâm và rửa lại nhiều lần đến khi nước rửa trong, sau đó phơi khô và xay nhuyễn; tiếp theo, cân $100 \mathrm{~g}$ mỗi loại chất mang cho riêng vào các túi nylon và khử trùng bằng nồi khử trùng nhiệt ướt 2 lần ở nhiệt độ $121^{\circ} \mathrm{C}$, mỗi lần cách nhau 24 giờ. Giá trị $\mathrm{pH}$ của 4 loại chất mang sau khi xử lý ở mức $6-6,5$. Trấu xay và cám gạo được xử lý thanh trùng tương tự như cách xử lý bã mía.

Chuẩn bị huyền phù VK: Ba dòng VK được cấy truyền trong môi trường thạch chuyên biệt, sau 48 giờ tiến hành dùng que cấy thu khuẩn lạc đơn cho vào chai thủy tinh $(500 \mathrm{~mL})$ chứa môi trường lỏng chuyên biệt cho từng dòng $\mathrm{VK}$ bao gồm: $300 \mathrm{~mL}$ môi trường $\mathrm{PB}, 300 \mathrm{~mL}$ môi trường $\mathrm{CB}, 300 \mathrm{~mL}$ môi trường $\mathrm{AB}$, nhân sinh khối trong 48 giờ và sử dụng dung dịch huyền phù để xác định mật số VK, sau cùng hiệu chỉnh dung dịch huyền phù $\mathrm{VK}$ về mật số $5 \times 10^{9} \mathrm{CFU} / \mathrm{mL}(9,7 \log \mathrm{CFU} / \mathrm{mL})$.

Chủng VK vào chất mang: Hút $20 \mathrm{~mL}$ huyền phù VK cho vào các túi chất mang (100 g/túi) đã được khử trùng, phối trộn để tế bào VK phân bố đều trong chất mang. Mật số VK trong chất mang là $9,7 \mathrm{log}$ $\mathrm{CFU} / \mathrm{g}$. Các chất mang sau khi chủng VK đạt ẩm độ 30-35\%, được bảo quản ở điều kiện tối và nhiệt độ phòng trong thời gian 6 tháng. Thí nghiệm được bố trí thành 3 thí nghiệm đơn cho mỗi dòng VK trên 4 loại chất mang là cám gạo, xơ dừa xay, bã mía, trấu xay và được tóm tắt trong Bảng 1 . Mỗi thí nghiệm đơn được bố trí hoàn toàn ngẫu nhiên với 5 nghiệm thức và ba lần lặp lại cho mỗi nghiệm thức. 
Bảng 1: Tóm tắt các nghiệm thức được bố trí cho các thí nghiệm khảo sát khả năng tồn trữ các dòng VK trên các chất mang

\begin{tabular}{lccccl}
\hline Dòng VK & \multicolumn{5}{c}{ Chất mang (100 g/túi) } \\
\cline { 2 - 6 } (10'CFU/g vật liệu) & Cám gạo & Xơ dừa xay & Bã mía & Trấu xay & Ghi chú \\
\hline Đối chứng âm & + & + & + & + & Sử dụng cho 3 thí nghiệm \\
pTVC3 & + & + & + & + & Thí nghiệm 1 \\
aCR1 & + & + & + & + & Thí nghiệm 2 \\
cAT1 & + & + & + & + & Thí nghiệm 3 \\
\hline
\end{tabular}

Ghi chú: “+”: các nghiệm thức được thục hiện trên các chất mang phục vụ thí nghiệm

Xác định mật số VK: Mật số VK trên nền chất mang tại các thời điểm $1,2,4,6$ tháng sau khi tồn trữ sử dụng các môi trường chuyên biệt như mô tả ở nội dung 2.1.

Xác định hoạt tính: Tại thời điểm 6 tháng sau khi tồn trữ, các chất mang chứa $\mathrm{VK}$ tồn trữ được trộn đều, sau đó cân $1 \mathrm{~g}$ chất mang để xác định mật số VK và xác định hoạt tính bằng phương pháp pha loãng và phương pháp khuếch tán trên đĩa thạch (Võ Dương Lan Anh, 2020). Hoạt tính enzyme của các dòng VK được xác định dựa vào bán kính vòng vô khuẩn của các dòng $\mathrm{VK}$ và được đánh giá theo phương pháp của Nguyễn Thị Thu Thủy và Nguyễn Tiến Long (2018).

\subsubsection{Khảo sát hiệu quả phân hủy rác thải hũu co của VK trên nền chất mang}

Chuẩn bị và xử lý mẫu rác: Thu rác thải hữu cơ được thải bỏ bao gồm rau cải, vỏ khoai, đầu cá vụn, ruột cá từ các chợ trên địa bàn thành phố Cần Thơ. Các mẫu rác được thu từ các chợ mang về và cắt nhỏ $(2-3 \mathrm{~cm})$ và cho vào thùng xốp $(20 \times 30 \times 20 \mathrm{~cm})$. Mỗi thùng chứa $1 \mathrm{~kg}$ rác thải hữu cơ gồm rau cải, vỏ khoai, đầu cá vụn với tỉ lệ $1: 1: 1$ và trộn chung lại thành một mẫu rác đồng nhất.

Chuẩn bị chế phẩm thử nghiệm: VK pTVC3 và $\mathrm{cAT} 1$ được tồn trữ trong chất mang xơ dừa và $\mathrm{aCR} 1$ được tồn trữ trong chất mang cám gạo giúp duy trì mật số và hoạt tính cho từng dòng $\mathrm{VK}$ chuyên biệt được phối trộn lại với nhau thành chế phẩm thử nghiệm chứa 3 dòng $\mathrm{VK}$ trên nền chất mang tương ứng với nhau theo tỉ lệ 1:1:1 (w/w) với mật số VK trong nền chất mang thử nghiệm đạt $8 \log \mathrm{CFU} / \mathrm{g}$ chế phẩm.

Chuẩn bị chế phẩm EM thử nghiệm (Viện Nghiên cứu và Phát triển Công nghệ Sinh học, Truờng Đai hoc Cần Tho nghiên cứu) được sử dụng để xử lý rác tại các cơ sở tập hợp nông sản. Thành phần của chế phẩm bao gồm nhóm VK phân giải cellulose, nhóm VK phân giải protein, nấm men và VK phân hủy tinh bột với mật số $10^{6} \mathrm{CFU} / \mathrm{mL}$ cho từng nhóm vi sinh vật. Chế phẩm được sử dụng theo hướng dẫn của đơn vị với $2 \mathrm{~mL}$ chế phẩm $\mathrm{EM}$ pha loãng trong $133 \mathrm{~mL}$ nước cất chứa sẵn trong bình tam giác $(250 \mathrm{~mL})$.

Chủng chế phẩm EM và chế phẩm thử nghiệm: Rải các chế phẩm thử nghiệm (100 g/túi) lần lượt vào các thùng rác đã được chuẩn bị và đảo trộn đều. Chế phẩm EM đã được pha loãng sau đó phun đều $45 \mathrm{~mL}$ lên mỗi thùng rác, đảo trộn và ủ các thùng rác trong điều kiện nhà lưới với thời gian 10 ngày.

Thí nghiệm được bố trí hoàn toàn ngẫu nhiên với 3 nghiệm thức và 3 lần lặp lại.

Nghiệm thức 1 (đối chứng âm): Rác phân hủy tự nhiên

Nghiệm thức 2 (đối chứng dương): Xử lý rác với chế phẩm EM thương mại

Nghiệm thức 3: Xử lý rác với hỗn hợp chất mang chứa 3 dòng VK (chế phẩm thử nghiệm).

Ở các thời điểm $0,3,5,7,10$ ngày sau ủ (NSU), mẫu rác được thu để xác định tỉ lệ phân hủy vật chất hữu cơ (TCVN 6648:2000). Tại thời 10 NSU, mẫu rác phân hủy được thu để phân tích $\mathrm{pH}$, chất hữu cơ (\% CHC) theo TCVN 9294:2012, và đạm tổng số (Nts) theo TCVN 10682:2015; xác định mật số $E$. coli bằng phương pháp MPN (most probable number; định tính Salmonella spp. bằng cách đếm khuẩn lạc trên đĩa petri chứa môi trường Salmonella - Shigella agar sau khi ủ 24 giờ ở $37^{\circ} \mathrm{C}$.

Đánh giá cảm quan: Dựa vào các chỉ tiêu mùi, màu sắc và trạng thái của vật liệu hữu cơ sau khi phân hủy với chỉ tiêu mùi được đánh giá cảm quan với các mức độ được trình bày ở Bảng 2 .

\section{Bảng 2: Mức độ đánh giá cảm quan mùi của vật liệu hữu cơ sau khi phân huỷ \\ Kí hiệu Ý nghĩa \\ - $\quad$ Không mùi \\ $+\quad$ Mùi nhẹ \\ ++ Mùi nặng, không chấp nhận được}


Ba dòng VK được trích DNA sử dụng bộ KIT QIAGEN DNeasy PowerLyzer microbial Kit, sử dụng cặp mồi 27F/1492R (Weisburg et al., 1991). Các sản phẩm PCR được gửi giải trình tự ở công ty KTEST Hồ Chí Minh. Trình tự đoạn gen 16S rDNA được so sánh với cơ sở dữ liệu của ngân hàng gen NCBI (National Center for Biotechnology Information).

\subsection{Xử lý số liệu}

Mật số VK trong các chất mang được trình bày đã trừ mật số VK hiện diện trong các chất mang ở các nghiệm thức đối chứng tương đương. Đường kính vòng phân giải, tỉ lệ phân hủy rác thải hữu cơ được xử lý bằng phần mềm Microsoft Excel (phiên bản 2016). Phân tích phương sai ANOVA và so sánh giữa các nghiệm thức bằng phần mềm Minitab 2016.

\section{KẾT QUẢ VÀ THẢO LUẬN}

\subsection{Khả năng sống sót và duy trì hoạt tính của các dòng $\mathrm{VK}$ trong chất mang}

\subsubsection{Mật số của VK phân hủy protein pTVC3}

Kết quả xác định mật số VK pTVC3 trong 4 chất mang được trình bày ở Bảng 3 , thời điểm ngay sau khi đóng gói (ngày 0 ), mật số VK pTVC3 ở các nghiệm thức với chất mang khác nhau khác biệt không có ý nghĩa thống kê, mật số đạt khoảng $10^{9}$ CFU/g chất mang.

Mật số VK pTVC3 trong 4 loại chất mang giảm dần qua 6 tháng tồn trữ. Ở thời điểm 6 tháng, chất mang xơ dừa xay cho hiệu quả duy trì mật số cao nhất đạt $8,02 \log \mathrm{CFU} / \mathrm{g}$ chất mang và khác biệt có ý nghĩa thống kê $(\mathrm{p}<0,01)$ so với các chất mang còn lại qua các giai đoạn khảo sát. Chất mang cám gạo và bã mía xay cho mật số trên $6 \log \mathrm{CFU} / \mathrm{g}$ chất mang. Chất mang trấu xay cho mật số đạt dưới 6 log CFU/g chất mang ở tháng thứ 5 nên không xác định mật số ở tháng thứ 6 đối với chất mang này (Bảng 3).

Chất mang là nơi lưu trú, đồng thời cho phép sự trao đổi khí, có hàm lượng chất hữu cơ cao và có khả năng giữ nước tốt (Rebah et al., 2002). Xơ dừa đáp ứng được các yêu cầu trên do trong xơ dừa có hàm lượng chất hữu cơ đến $89 \%$, ngoài ra còn có các nguyên tố khoáng như kali, canxi, magie (Asiah et al., 2004), tạo điều kiện thích hợp để duy trì mật số VK. Kết quả này cũng tương tự như kết quả của Nguyễn Khởi Nghĩa và Nguyễn Thị Kiều Oanh (2017) khi bổ sung mụn dừa có chức năng giúp chất nền thoáng khí và điều này giúp duy trì mật số $\mathrm{VK}$ cao hơn $8 \log \mathrm{CFU} / \mathrm{g}$ chất mang.

Bảng 3: Mật số của VK pTVC3 ( $\log \mathrm{CFU} / \mathrm{g}$ chất mang) theo thời gian tồn trũ

\begin{tabular}{lrrrr}
\hline Chất mang & \multicolumn{4}{c}{ Mật số VK $(\log$ CFU/g chất mang) theo thời gian tồn trữ } \\
\cline { 2 - 5 } & $\mathbf{1}$ tháng & $\mathbf{2}$ tháng & $\mathbf{4}$ tháng & 6 tháng \\
\hline Cám gạo & $9,47^{\mathrm{a}}$ & $8,71^{\mathrm{a}}$ & $7,63^{\mathrm{b}}$ & $6,19^{\mathrm{b}}$ \\
Xơ dừa xay & $8,82^{\mathrm{b}}$ & $8,69^{\mathrm{a}}$ & $8,48^{\mathrm{a}}$ & $8,02^{\mathrm{a}}$ \\
Trấu xay & $7,93^{\mathrm{d}}$ & $7,79^{\mathrm{c}}$ & $6,69^{\mathrm{d}}$ & $\mathrm{KXÐ}$ \\
Bã mía xay & $8,41^{\mathrm{c}}$ & $8,04^{\mathrm{b}}$ & $6,91^{\mathrm{c}}$ & $6,17^{\mathrm{b}}$ \\
Mức ý nghĩa (\%) & $* *$ & $* *$ & $* *$ & $* *$ \\
CV (\%) & 2,70 & 2,04 & 4,03 & 5,63 \\
\hline
\end{tabular}

Ghi chú: Trong cùng một cột, nhũng số có các ký tụ theo sau khác nhau thì khác biệt có ý nghĩa thống kê ở mức 1\% (**) qua kiểm định Tukey. Mật số VK được chuyển sang Log10 khi phân tích thống kê, KXĐ: không xác định.

\subsubsection{Mật số của VK phân hủy tinh bột aCRI}

Kết quả xác định mật số VK aCR1 trong 4 loại chất mang được trình bày ở Bảng 4 . Thời điểm ngay sau khi chủng (ngày 0 ), mật số VK aCR1 trong các nghiệm thức với các chất mang khác nhau khác biệt không có ý nghĩa thống kê và mật số đạt khoảng 9 $\log \mathrm{CFU} / \mathrm{g}$ chất mang. Mật số VK trong 4 loại chất mang này có $\mathrm{xu}$ hướng giảm dần từ tháng thứ hai đến tháng thứ 6 và chỉ có cám gạo cho mật số duy trì đạt cao nhất trên $7 \log \mathrm{CFU} / \mathrm{g}$ chất mang ở tháng thứ 6 và khác biệt có ý nghĩa thống kê $(\mathrm{p}<0,01)$ so với mật số VK trong các chất mang còn lại. Trong bốn loại chất mang, chất mang cám gạo có thành phần tinh bột đạt cao nhất chiếm khoảng $16-20 \%$ tinh bột (Sharma et al., 2004) và do dòng $\mathrm{aCR} 1$ là VK phân giải tinh bột nên môi trường cám gạo vừa giúp làm nơi ở vừa là nguồn cung cấp thức ăn thích hợp cho VK này (Đặng Hoài An và ctv., 2017). 
Bảng 4: Mật số của VK aCR1 (log CFU/g chất mang) theo thời gian tồn trũ̃

\begin{tabular}{lrrrr}
\hline \multirow{2}{*}{ Chất mang } & \multicolumn{4}{c}{ Mật số VK $(\log$ CFU/g chất mang) theo thời gian tồn trũ } \\
\cline { 2 - 5 } & $\mathbf{1}$ tháng & $\mathbf{2}$ tháng & $\mathbf{4}$ tháng & 6 tháng \\
\hline Cám gạo & $8,87^{\mathrm{a}}$ & $8,65^{\mathrm{a}}$ & $8,47^{\mathrm{a}}$ & $7,91^{\mathrm{a}}$ \\
Xơ dừa xay & $8,45^{\mathrm{b}}$ & $7,33^{\mathrm{c}}$ & $5,92^{\mathrm{d}}$ & $\mathrm{KXÐ}$ \\
Trấu xay & $7,98^{\mathrm{c}}$ & $7,61^{\mathrm{c}}$ & $6,61^{\mathrm{c}}$ & $5,82^{\mathrm{c}}$ \\
Bã mía xay & $8,52^{\mathrm{b}}$ & $8,00^{\mathrm{b}}$ & $7,37^{\mathrm{b}}$ & $6,43^{\mathrm{b}}$ \\
Mức ý nghĩa (\%) & $* *$ & $* *$ & $* *$ & $* *$ \\
CV (\%) & 2,04 & 2,07 & 5,83 & 5,82 \\
\hline
\end{tabular}

Ghi chú: Trong cùng một cột, nhũng số có các ký tụ theo sau khác nhau thì khác biệt có ý nghĩa thống kê ở mức 1\% (**) qua kiểm định Tukey. Mật số VK được chuyển sang Log10 khi phân tích thống kê, KXĐ: không xác định.

\subsubsection{Mật số của VK phân giải cellulose cAT1}

Tại thời điểm ngay sau khi chủng (ngày 0 ), mật số VK cAT1 ở các nghiệm thức chất mang khác nhau thì khác biệt không có ý nghĩa thống kê (Bảng 5). Tại thời điểm 1 tháng sau khi chủng, chất mang xơ dừa xay có mật số đạt cao nhất với $8,72 \log$ CFU/g chất mang và khác biệt có ý nghĩa thống kê $(\mathrm{p}<0,01)$ so với hai nghiệm thức chất mang còn lại. Từ tháng thứ 4 đến tháng thứ 6 , mật số VK được tồn trữ trong 4 loại chất mang khác đều giảm dần, chỉ có chất mang xơ dừa xay giúp duy trì mật số VK đạt trên $7 \log \mathrm{CFU} / \mathrm{g}$ chất mang, cao nhất và khác biệt có ý nghĩa thống kê so với các nghiệm thức còn lại ( $\mathrm{p}<0,01)$. Với các ưu điểm độ thoáng khí cao, $\mathrm{pH}$ ở mức trung tính, thành phần cellulose hiện diện trong mụn dừa dao động trong khoảng $20 \%$ thích hợp cho VK cAT1 duy trì mật số. Theo You et al. (2012),

Bảng 5: Mật số của VK cAT1 (log CFU/g chất mang) theo thời gian tồn trữ

\begin{tabular}{lrrrr}
\hline \multirow{2}{*}{ Chất mang } & \multicolumn{4}{c}{ Mật số VK (log CFU/g chất mang) } \\
\cline { 2 - 5 } & 1 tháng & 2 tháng & 4 tháng & 6 tháng \\
\hline Cám gạo & $6,90^{\mathrm{c}}$ & $6,68^{\mathrm{c}}$ & $5,80^{\mathrm{d}}$ & KXÐ \\
Xơ dừa xay & $8,72^{\mathrm{a}}$ & $8,25^{\mathrm{a}}$ & $7,96^{\mathrm{a}}$ & $7,82^{\mathrm{a}}$ \\
Trấu xay & $8,16^{\mathrm{b}}$ & $7,85^{\mathrm{b}}$ & $6,40^{\mathrm{c}}$ & $6,40^{\mathrm{b}}$ \\
Bã mía xay & $8,16^{\mathrm{b}}$ & $7,96^{\mathrm{b}}$ & $6,59^{\mathrm{b}}$ & $6,31^{\mathrm{c}}$ \\
Mức ý nghĩa (\%) & $* *$ & $* *$ & $* *$ & $* *$ \\
CV (\%) & 3,67 & 3,48 & 5,15 & 4,45 \\
\hline
\end{tabular}

Ghi chú: Trong cùng một cột, nhũng số có các ký tụ theo sau khác nhau thì khác biệt có ý nghĩa thống kê ở mức 1\% (**) qua kiểm định Tukey. Mật số VK được chuyển sang Log10 khi phân tích thống kê, KXĐ: không xác định.

\subsubsection{Khả năng duy trì hoạt tính của các dòng} VK trên các công thức chất mang

Kết quả đánh giá hoạt tính phân giải protein, tinh bột và cellulose lần lượt của 3 dòng VK $\mathrm{pTVC}$, $\mathrm{aCR} 1$ và $\mathrm{cAT} 1$ trong các loại chất mang cám gạo, xơ dừa xay, bã mía xay và trấu xay được trình bày trong Bảng 6 . Nhìn chung, cả 3 dòng $\mathrm{VK}$ được tồn trữ trong các loại chất mang đều có đường kính vòng phân giải chênh lệch không đáng kể sau 6 tháng tồn trữ. Cụ thể dòng $\mathrm{pTVC} 3$ có đường kính vòng phân
VK có khả năng phân giải cellulose thường không sử dụng protein hay lipid làm nguồn năng lượng cho sự sinh trưởng, vì vậy mật số VK cAT1 đạt thấp nhất ở thời điểm 4 tháng trong chất mang cám gạo. Do mật số VK thấp hơn $6 \log \mathrm{CFU} / \mathrm{g}$ chất mang ở tháng thứ 4 nên nghiệm thức chất mang cám gạo không xác định mật số trong chất mang ở tháng thứ 6 . Chất mang bã mía xay và trấu xay cũng gồm các thành phần như cellulose, lignin, hemi - cellulose giúp duy trì mật số ở mức trên $6 \log \mathrm{CFU} / \mathrm{g}$ sau 6 tháng. Tuy nhiên, có thể do hàm lượng Si hiện diện trong trấu xay cao (khoảng 20\%) cũng như các hợp chất bền trong bả mía nên ảnh hưởng đến hoạt tính cellulase của VK (Patil et al., 2014; Michelin et al., 2016; Molo et al., 2021) từ đó có thể là nguyên nhân dẫn đến mật số của VK đạt thấp hơn so với chất mang xơ dừa xay.

giải dao động trong khoảng 18,93 - 21,03 mm, dòng $\mathrm{aCR} 1$ có vòng phân giải đạt $16-19,03 \mathrm{~mm}$ và dòng cAT1 đạt trong khoảng 16,67- 18,57 mm (Bảng 6).

Các kết quả trên cho thấy chất mang xơ dừa cho hiệu quả duy trì mật số và hoạt tính đối với 2 dòng VK phân giải protein $\mathrm{pTVC} 3$ và dòng $\mathrm{VK}$ phân giải cellulose cAT1; chất mang cám gạo thích hợp để duy trì mật số và hoạt tính cho dòng $\mathrm{aCR} 1$ đến 6 tháng. 


\section{Bảng 6: Đường kính vòng phân giải của ba dòng VK sau 6 tháng tồn trũ̃}

\begin{tabular}{lccr}
\hline \multirow{2}{*}{ Nghiệm thức } & \multicolumn{4}{c}{ Đường kính vòng phân giải sau 6 tháng $(\mathbf{m m})$} & cAT1 \\
\cline { 2 - 4 } & p.TVC3 & aCR1 & $16,67 \pm 0,25$ \\
Cám gạo & $19,73 \pm 0,45$ & $19,03 \pm 0,25$ & $18,57 \pm 0,32$ \\
Xơ dừa xay & $21,03 \pm 0,32$ & $17,23 \pm 0,47$ & $17,03 \pm 0,25$ \\
Trấu xay & $19,00 \pm 0,20$ & $16,00 \pm 0,36$ & $18,57 \pm 0,25$ \\
Bã mía xay & $18,93 \pm 0,85$ & $17,37 \pm 0,51$ & \\
\hline
\end{tabular}

Ghi chú: Giá trị trung bình của đưòng kính vòng halo xuất hiện trên môi truòng chuyên biệt (土: độ lệch chuẩn SD, $n=3)$.

\subsection{Khả năng phân hủy rác thải hữu cơ của VK tồn trữ trong chất mang}

\subsubsection{Khả năng phân hủy rác thải hũu co}

Kết quả đánh giá khả năng phân hủy rác thải hữu cơ từ các chế phẩm thử nghiệm cho thấy nghiệm thức rác phân hủy tự nhiên có tỉ lệ phân hủy đạt $55 \%$ ở giai đoạn 3 ngày sau khi ủ (NSU) và đạt thấp nhất so với 2 nghiệm thức còn lại (Hình 1). Trong nghiệm thức, chế phẩm EM và chế phẩm thử nghiệm cho tỉ lệ phân hủy rác thải hữu cơ trên $80 \%$ ở 3 NSU được sử dụng, trên $95 \%$ ở $10 \mathrm{NSU}$ và khác biệt giữa 2 nghiệm thức này không có ý nghĩa thống kê
( $\mathrm{p}>0,01)$. Điều này cũng phù hợp với nhận xét của Lê Phú Tuấn (2016) là sử dụng vi sinh vật giúp đẩy nhanh quá trình phân hủy chất hữu cơ, tăng hiệu quả xử lý. Do đó, ở nghiệm thức rác phân hủy tự nhiên, tốc độ phân hủy chậm hơn so với bổ sung chế phẩm vi sinh. Tuy nhiên, các dòng $\mathrm{VK}$ nghiên cứu là những dòng VK bình nhiệt (kết quả thí nghiệm 1) nên chúng hoạt động rất mạnh vào những ngày đầu khi nhiệt độ khối ủ trong khoảng $28-45^{\circ} \mathrm{C}$, do đó cho hiệu quả phân hủy trên $80 \%$ ở 3 NSU. Nhưng từ giai đoạn 5 NSU đến 10 NSU, hiệu quả phân hủy chỉ tăng thêm khoảng $15 \%$.

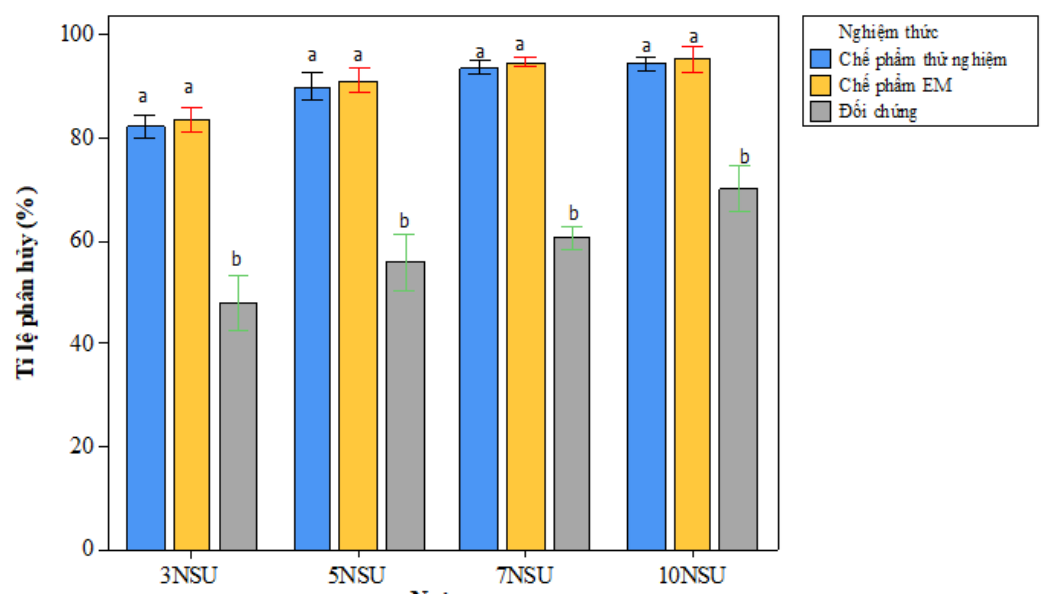

Hình 1. Kết quả khả năng phân hủy rác thải của ba nghiệm thức

Ghi chú: Trong cùng thời gian ủ, nhũng cột các ký tư trên cùng khác nhau thì khác biệt có ý nghĩa thống kê ở mức 5\%; thanh biến động là độ lệch chuẩn $(n=3)$.

\subsubsection{Kết quả đánh giá cảm quan rác sau khi ủ}

Đánh giá cảm quan của rác thải hữu cơ sau khi phân hủy cũng được xem là chỉ tiêu giúp hỗ trợ đánh giá chất lượng của phân hữu cơ. Mùi và màu sắc của phân hữu cơ cũng giúp đánh giá mức độ hoai mục của phân hữu cơ. Kết quả đánh giá cảm quan ở Bảng 7 và Hình 2 cho thấy ở NT1 (đối chứng), sản phẩm sau thời gian phân hủy có mùi hôi khó chịu, rác phân hủy ướt. Nghiệm thức xử lý chế phẩm EM cho hiệu quả phân hủy rác hữu cơ cao nhất. Tuy nhiên, rác sau khi phân hủy ẩm ướt, có màu vàng xanh và có mùi hôi. Nghiệm thức xử lý với chế phẩm thử nghiệm cho kết quả tốt nhất với rác sau khi phân hủy ở trạng thái hỗn hợp ẩm, tơi xốp, có màu đen nâu, không mùi hôi. Theo nghiên cứu của Lê Phú Tuấn (2016), ủ phụ phế phẩm nông nghiệp bằng chế phẩm sinh học Anti-Tricho cho kêt quả hàm lượng dinh dưỡng $\mathrm{N}, \mathrm{P}, \mathrm{K}$ cao hơn mẫu phụ phế phẩm phân hủy tự nhiên và sản phẩm sau 28 ngày ủ ở trạng thái tơi 
xốp, có màu đen xám, sẵn sàng mang đi bón cây. Qua đó cho thấy kết quả phân hủy của rác thải hữu cơ của chế phẩm thử nghiệm tương tự như các kết quả đã được công bố trong cùng lĩnh vực.

Bảng 7: Kết quả đánh giá cảm quan của rác thải hữu cơ sau 10 ngày ủ

\begin{tabular}{|c|c|c|c|}
\hline \multirow{2}{*}{ Nghiệm thức } & \multicolumn{3}{|c|}{ Đánh giá cảm quan } \\
\hline & Màu sắc & Mùi & Trang thái \\
\hline NT1: Rác phân hủy tự nhiên & Xanh & ++ & Âm ướt \\
\hline NT2: Chế phẩm EM & Vàng xanh & ++ & Âmm ướt \\
\hline NT3: Chế phẩm thử nghiệm & Nâu đen & - & Tơi xốp, ẩm \\
\hline
\end{tabular}

Ghi chú: (-) không mùi, (+) mùi nhẹ chấp nhận được, (++) mùi nặng không chấp nhận đượ.
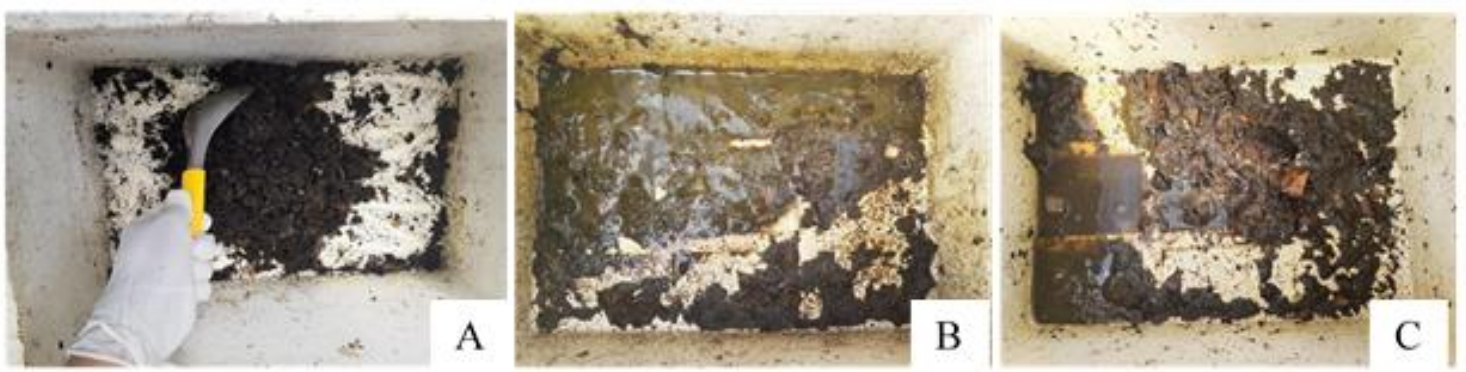

Hình 2. Mẫu rác thải phân hủy 10 ngày sau ủ

Ghi chú: (A) rác thải ủ với chế phẩm thủ nghiệm - NT3, (B) rác thải ủ với chế phẩm EM-NT2, (C) rác thải phân hủy tụ nhiên-NT1.

\section{Bảng 8: Kết quả mật số vi sinh vật gây hại và thành phần hóa học của rác thải sau 10 ngày ủ}

\begin{tabular}{lrrrc}
\hline \multirow{2}{*}{ Nghiệm thức } & $\begin{array}{c}\text { Chỉ tiêu hóa học } \\
\text { (hàm lượng trên vật chất khô) }\end{array}$ & \multicolumn{2}{c}{$\begin{array}{c}\text { Chỉ tiêu sinh học } \\
\text { Mật số VK/1g mầu tươi }\end{array}$} \\
\cline { 2 - 5 } & $\% \mathbf{C H C}$ & $\% \mathbf{N}$ & $\begin{array}{c}\boldsymbol{E} \text { c coli } \\
(\mathbf{M P N} / \mathbf{( 1 )})\end{array}$ & $\begin{array}{c}\text { Salmonella } \text { spp. } \\
\text { (CFU/g) }\end{array}$ \\
\hline NT1: Rác phân hủy tự nhiên & 77,8 & 3,85 & 54,0 & $\mathrm{KPH}^{(2)}$ \\
NT2: Chế phẩm EM & 51,8 & 4,17 & 1019 & $\mathrm{KPH}$ \\
NT3: Chế phẩm thử nghiệm & 74,1 & 4,81 & 5,4 & $\mathrm{KPH}$ \\
Quy định theo TCVN & TCVN 9294:2012 & TCVN 8557:2010 & $<1,1.10^{3}$ & $\mathrm{KPH}$ \\
\hline
\end{tabular}

Ghi chú: (1): most probable number, ${ }^{(2)}$ KPH: Không phát hiện.

Như vậy, khả năng phân hủy rác thải hữu cơ của chế phẩm thử nghiệm tương đương với chế phẩm EM thương mại, rác thải sau phân hủy đạt được các yêu cầu về chất lượng phân bón hữu cơ, mật số vi sinh vật có hại dưới ngưỡng cho phép theo TCVN.

Kết quả định danh ba dòng VK cho thấy dòng VK có khả năng phân hủy protein pTVC3 thuộc loài Pseudomonas aeruginosa (NR113599.1) với độ tương đồng $100 \%$. Dòng VK có khả năng phân hủy tinh bột cAT1 thuộc loài Serratia marcescens (NR114043.1) với độ tương đồng $99,1 \%$ và dòng VK có khả năng phân giải cellulose aCR1 thuộc chi Klebsiella sp. (NR117683.1) với độ tương đồng $94 \%$.

\section{KẾT LUẬN}

Xơ dừa xay là loại chất mang phù hợp nhất được tuyển chọn để duy trì mật số và hoạt tính của hai dòng $\mathrm{VK}$ pTVC3 và cAT1; cám gạo thích hợp làm chất mang cho dòng $\mathrm{VK}$ aCR1 với mật số đạt ngưỡng $7-8 \log \mathrm{CFU} / \mathrm{g}$ chất mang và giúp duy trì hoạt tính enzyme sau 6 tháng tồn trữ. Kết quả đánh giá hiệu quả phân hủy rác thải hữu cơ cho thấy chế phẩm VK trên các nền chất mang được tuyển chọn cho hiệu quả phân hủy rác thải hữu cơ đạt $80 \%$ sau 3 ngày ủ và $95 \%$ ở 10 NSU. Rác thải hữu cơ sau 10 ngày ủ không có mùi hôi, tơi xốp, có màu nâu đen, hàm lượng chất hữu cơ và $\mathrm{N}$ tổng số đạt tiêu chuẩn theo quy định về chất lượng trong phân bón hữu cơ. Không phát hiện Salmonella spp. và mật số $E$. coli ở mức cho phép theo TCVN 6846:2007. Như vậy, rác thải hữu cơ sau khi phân hủy với chế phẩm thử nghiệm đảm bảo độ an toàn khi bón cho cây.

\section{LỜI CẢM TẠ}

Nhóm tác giả xin chân thành cảm ơn Trường Đại học Cần Thơ và dự án Nâng cấp Trường Đại học Cần Thơ VN14-P6 bằng nguồn vốn vay ODA-E6 từ 
Chính phủ Nhật đã hỗ trợ kinh phí để thực hiện đề tài sinh viên nghiên cứu khoa học.

\section{TÀI LIỆU THAM KHẢO}

Arbaciauskiene, V. (2003). Extracellular enzyme activities of aquatic bacteria in polluted environment: 2. Amylolytic activity. Lietuvos Mokslu Akademija. Ekologija, 34-38.

Asiah, A., MohdRazi, I., MohdKhanif, Y., Marziah, M. \& Shaharuddin, M. (2004). Physical and chemical properties of coconut coir dust and oil palm empty fruit bunch and the growth of hybrid heat tolerant cauliflower plant. Pertanika Journal of Tropical Agricultural Science, 27(2), 121.

Đặng Hoài An, Nguyễn Thị Phi Oanh \& Nguyễn Đắc Khoa. (2017). Tuyển chọn chất mang để tồn trữ vi khuẩn Bacillus aerophilus đối kháng với vi khuẩn Xanthomonas oryzae pv. oryzae gây bệnh cháy bìa lá lúa. Tap chí Khoa hoc Trường Đại hoc Cần Tho, 52b, 8-15.

Hà Thanh Toàn, Mai Thu Thảo, Nguyễn Thu Phướng, Trần Lê Kim Ngân, Bùi Thế Vinh \& Cao Ngọc Điệp. (2008). Phân lập vi khuẩn phân giải cellulose, tinh bột và protein trong nước rỉ từ bãi rác ở thành phố Cần Thơ. Tạp chi Khoa học Truờng Đại hoc Cần Tho, 10, 195-202.

Lê Phú Tuấn, Vũ Thị Kim Oanh \& Nguyễn Thị Thu Phương. (2016). Nghiên cứu và xử lý phụ phẩm nông nghiệp thành phân hữu cơ sử dụng chế phẩm vi sinh tại xã Phúc Thuận, Phỗ Yên, Thái Nguyên. Tạp chi Khoa hoc và Công nghệ Lâm nghiẹp, 6, $101-108$.

Michelin, M., Ximenes, E., de Moraes, M.D.L.T. \& Ladisch, M.R. (2016). Effect of phenolic compounds from pretreated sugarcane bagasse on cellulolytic and hemicellulolytic activities. Bioresource Technology, 199, 275-278.

Molo, A.D.R., Susanti, E. and Wonorahardjo, S. (2021). Application of silica rice husk ash for cellulase immobilized by sol-gel entrapment. Chemistry \& Chemical Engineering, Biotechnology, Food Industry, 22(1), 47-55.

Nguyễn Hoàng Hậu. (2020). Phân lập các dòng vi khuẩn có khả năng tiết enzyme amylase, cellulase và proteases giúp phân hủy tinh bọt, cellulose và protein trong rác thải sinh hoạt ở các chơ, quán ăn và hộ gia đình trên địa bàn thành phố Cần Tho. Đề tài sinh viên nghiên cứu khoa học Trường Đại hoc Cần Thơ TSV2019 - 127.

Nguyễn Khởi Nghĩa \& Nguyễn Thị Kiều Oanh. (2017). Tuyển chọn chất mang và chất nền sản xuất chế phẩm vi sinh chứa ba dòng vi khuẩn chịu mặn kích thích sinh trưởng cây trồng Burkholderia cepacia BL1 - 10, Bacillus megaterium ST2-9 và Bacillus aquimaris KG6-3 . Tạp chí Công nghệ Sinh học Đại học Cần Tho, 15(2), 381-392.
Nguyễn Thị Thu Thủy \& Nguyễn Tiến Long. (2018). Vi sinh vật phân giải cellulose mạnh trong sản xuất phân hữu cơ từ phế phụ phẩm nông nghiệp và ảnh hưởng của chúng đối với giống Lạc L14 tại Hương Trà, Thừa Thiên Huế. Tạp chí khoa học Đại học Huế, 127(3B), 5-19.

Nguyễn Xuân Thành. (2003). Giáo trình công nghệ vi sinh vật trong sản xuất nông nghiệp và xủ lý $\hat{o}$ nhiếm môi truoòng. Nhà Xuất bản Nông nghiệp Hà Nội, Hà Nội.

Patil, R., Dongre, R. \& Meshram, J. (2014). Preparation of silica powder from rice husk. Journal of Applied Chemistry, 27, 26-29.

Rebah, F.B., Tyagi, R.D. \& Prevost, D. (2002). Wastewater sludge as a substrate for growth and carrier for rhizobia: the effect of storage conditions on survival of Sinorhizobium meliloti. Bioresource Technology, 83(2), 145-151.

Ryckeboer, J., Mergaert, J., Coosemans, J., Deprins, K., \& Swings, J. (2003). Microbiological aspects of biowaste during composting in a monitored compost bin. Journal of Applied Microbiology, 94(1), 127-137.

Sharma, H.R., Chauhan, G.S. \& Agrawal, K. (2004). Physico-chemical characteristics of rice bran processed by dry heating and extrusion cooking. International Journal of Food Properties, 7(3), 603-614.

Smith, R. S. (1992). Legume inoculant formulation and application. Canadian Journal of Microbiology, 38(6), 485-492.

Bộ Khoa học và Công nghệ. (2015). TCVN 10682:2015: Phân bón - xác định hàm luợng nitrat - phuong pháp kjeldahl.

https://vanbanphapluat.co/tcvn-10682-2015phan-bon-xac-dinh-ham-luong-nitrat-phuongphap-kjeldahl.

Bộ Khoa học và Công nghệ. (2005). TCVN 4829:2005: Vi sinh vật trong thưc phẩm và thưc ăn chăn nuôi-phuoong pháp phát hiện Salmonella trên đĩa thach. https://vanbanphapluat.co/tcvn-4829-2005-visinh-vat-trong-thuc-pham-va-thuc-an-chan-nuoi.

Bộ Khoa học Công nghệ và Môi trường. (2000). TCVN 6648: 2000: Chất luợng đất-xác định chất khô và hàm lương nước theo khối luợng. https://vanbanphapluat.co/tcvn-5963-1995-chatluong-dat-xac-dinh-chat-kho-va-ham-luong-nuoc.

Bộ Khoa học và Công nghệ. (2007). TCVN 6846:2007: Vi sinh vật trong thực phẩm và thưc ăn chăn nuôi - phuoong pháp phát hiện và định luợng Escherichia coli giả định- kỹ thuật đếm số có xác suất lớn nhất. https://vanbanphapluat.co/tcvn-6846-2007-visinh-vat-trong-thuc-pham-va-thuc-an-chan-nuoi.

Bộ Khoa học và Công nghệ. (2010). TCVN 8557:2010: Phân bón-phuoong pháp xác định 
nito tổng số. https://vanbanphapluat.co/tcvn8557-2010-phan-bon-phuong-phap-xac-dinhnito-tong-so.

Bộ Khoa học và Công nghệ. (2021). TCVN 9294:2012: Phân bón-xác định cacbon hũu co tổng số bằng phuơng pháp Walkley-Black. https://vanbanphapluat.co/tcvn-9294-2012-phanbon-xac-dinh-cacbon-tong-so-bang-phuongphap-walkley.

Võ Dương Lan Anh, Nguyễn Thiện Mỹ, Nguyễn Thị Cẫm Hơn \& Nguyễn Hoàng Hậu. (2020). Nghiên cúu chất mang giúp tồn trũ vi khuẩn phân giải rác thải hũu co tại các chọ trên địa bàn thành phố Cần Tho: Báo cáo tổng kết đề tài sinh viên nghiên cứu khoa học, Đại học Cần Thơ.

Weisburg, W. G., Barns, S. M., Pelletier, D. A., \& Lane D. J. (1991). 16S ribosomal DNA amplification for phylogenetic study. J Bacteriol, 173(2), 697-703.

You, C., Zhang, X. Z., Sathitsuksanoh, N., Lynd, L. R., \& Zhang, Y. H. P. (2012). Enhanced microbial utilization of recalcitrant cellulose by an ex vivo cellulosome-microbe complex. Applied and environmental microbiology, 78(5), 1437-1444. 